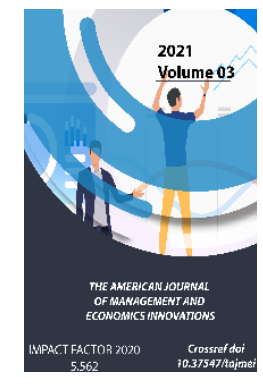

Journal Website: https://theamericanjou rnals.com/index.php/ta jmei

Copyright: Original content from this work may be used under the terms of the creative commons attributes 4.0 licence.

\section{Possibilities Of The Uacser Model To Increase The Efficiency Of Using Clasters And Synergetics}

Prof. Mamayunus K. Pardaev

Samarkand Institute Of Economics And Service, Uzbekistan

Akbar Rizaevich Egamov

Master's Student, Samarkand Institute Of Economics And Service, Uzbekistan

\title{
ABSTRACT
}

The article discusses the possibilities of using the UACSER model to increase the efficiency of clustering and synergetics. This model uses factors and processes such as interest, activity, cluster, synergetics, efficiency, outcome, and is based on their interdependence. A noteworthy aspect is the interdependence of synergetics with the cluster.

\section{KEYWORDS}

Interest, Activity, Cluster, Synergetics, Efficiency, Result, Model.

\section{INTRODUCTION}

Relevance of the topic. Any activity, no matter what, must end with an effective outcome. Only then will the interests of the initiator, the investor, the participants in the activity, the state and society be met accordingly. Another important aspect is the increased competitiveness of the entity (enterprise, organization, LLC, joint stock company, network, etc.) that has achieved this result.
There are many ways to increase competitiveness. At present, one of them is the joint use of cluster and synergetic methods in various fields. 


\section{THE MAIN RESULTS AND FINDINGS}

In this regard, in the Address of the President of the Republic of Uzbekistan Shavkat Mirziyoyev to the Supreme Court on January 28,2020 , he said: We will continue to work to establish clusters that meet today's needs in other sectors, such as fruit and vegetables, rice, livestock, silk. It is necessary to take measures to sharply increase crop production to export $\$ 2$ billion this year and 3-4 times more fruits and vegetables in the next 5-7 years. "If the parliament had adopted a new law on cooperation and clusters, which is the legal basis for these reforms, it would have been in line with our grand plans and intentions," he said. ${ }^{1}$

It would not be a mistake to say that today there is no network without the cluster method. As a result, there is a need for a law on cooperatives and clusters. All of this evidence ultimately determines the relevance of this research topic.

1 Address of the President of the Republic of Uzbekistan Shavkat Mirziyoyev to the Oliy Majlis of

\section{ANALYSIS AND RESULTS}

Today, the question naturally arises as to why it is necessary to use a cluster. Because it is a new untested direction, a number of other questions are still waiting to be answered as to whether it can always be effective. Our research has shown that forces come together through a cluster, where the result is achieved faster. The process of achieving a synergistic effect takes place. This, in turn, leads to lower cost of goods (works and services), strengthening the competitiveness of entities operating in this area. This process will ultimately ensure the well-being of the population.

Our research has shown that it is advisable to use the capabilities of the interrelated UACSER model to increase the efficiency of cluster and synergetic use. Due to this, we developed the MFKSSN model. As for its content, it consists of the following. $U$ - useful, A - activity, $C$ - use of cluster, $S$ - use of synergetics, $E$ achievement of efficiency, $R$ - high result. An explanation of this is given in the following figure (Figure 1).
January 28, 2020.// "Xalq so'zi” newspaper January 30, 2020.- Pages 1-3. 

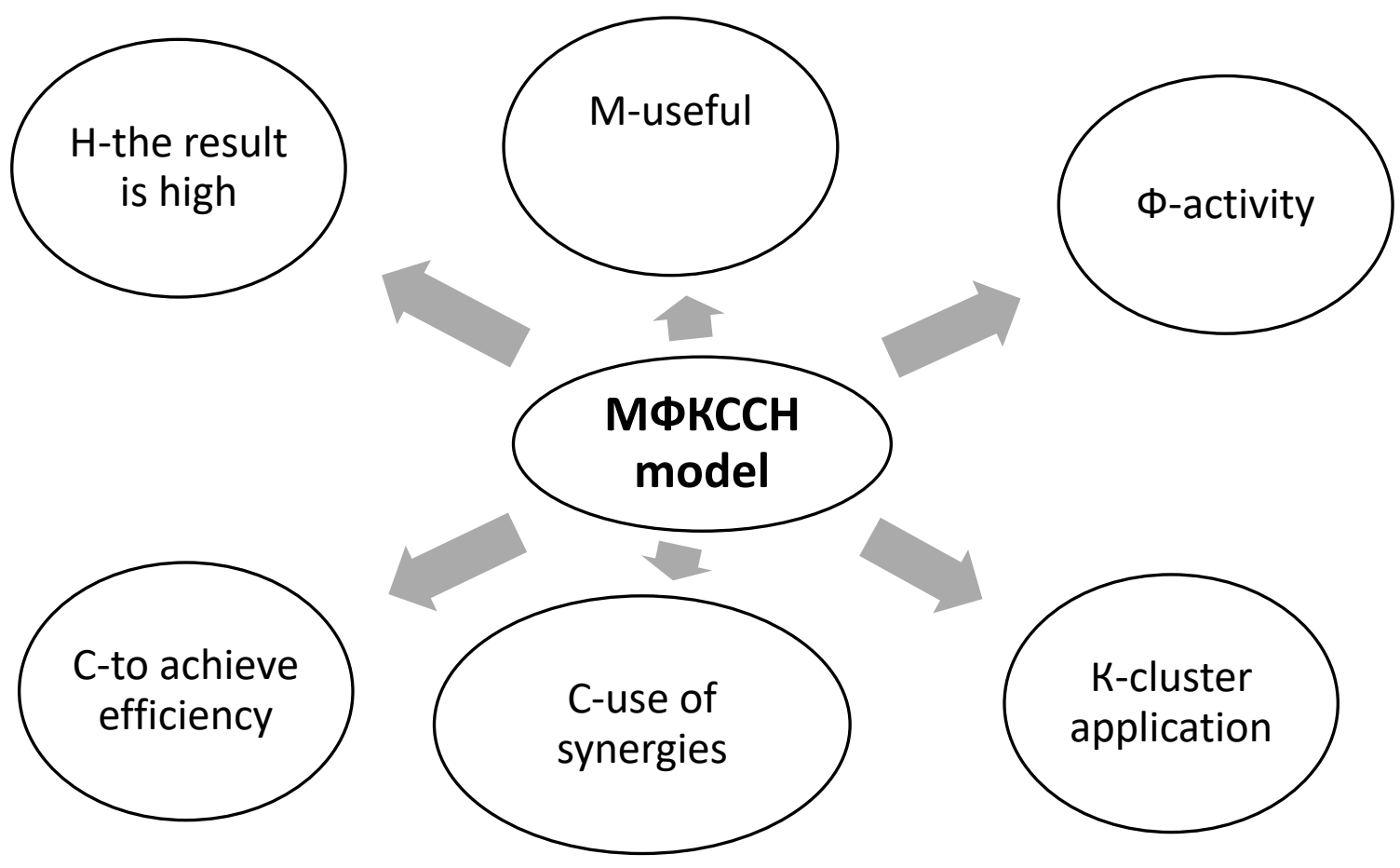

Figure 1. The interdependence of factors aimed at achieving high efficiency using cluster and synergistic effects

In our country, great efforts are being made to use the cluster method. Because combining forces through a cluster is an important factor in achieving synergistic efficiency. As a result, a model has been developed to achieve high efficiency using the interdependence of these factors. We found it expedient to explain all the activities included in this model, the process factors. This is shown in the table below (Table 1).

Table 1.

The structure of the UACSER model and their interpretation

\begin{tabular}{|c|c|c|}
\hline T/p & $\begin{array}{c}\text { Types of } \\
\text { activities and } \\
\text { processes in the } \\
\text { model }\end{array}$ & An explanation of the types of activities and processes in the model \\
\hline 1. & $\mathrm{U}$ - useful & $\begin{array}{c}\text { The goal of starting any business is to make a certain amount of } \\
\text { profit. Without interest, there will be no activity and, accordingly, no } \\
\text { clue on the application of cluster, syneretic methods. As a result, } \\
\text { interest in the use of clusters and synergies is as high as interest at } \\
\text { the beginning of any work.. }\end{array}$ \\
\hline
\end{tabular}




\begin{tabular}{|c|c|c|}
\hline 2. & A- activity & $\begin{array}{l}\text { It is possible to obtain activities carried out in various sectors of the } \\
\text { economy (production, services, creation of tangible and intangible } \\
\text { goods, etc.). If there is no activity in the growth of dreams, no } \\
\text { interest will be realized. This includes the interests of the } \\
\text { entrepreneur, the employee, the cluster or synergetic entities, the } \\
\text { state and the people. As a result, all entities are interested in } \\
\text { carrying out the activity. }\end{array}$ \\
\hline 3. & $\begin{array}{l}\text { K- Using the } \\
\text { cluster }\end{array}$ & $\begin{array}{l}\text { The cluster method is used to ensure that one entity is responsible for } \\
\text { the selected activity from start to end (e.g., from field to table) and } \\
\text { that it controls the entire chain of activities. In this method, at all } \\
\text { stages, the products are not sold to each other, but transferred from } \\
\text { one to another. As a result, the cheapness of the product (service) is } \\
\text { ensured and, accordingly, its competitiveness is strengthened. The } \\
\text { profits are distributed equally according to the contribution of each. } \\
\text { This is very important in the competition. }\end{array}$ \\
\hline 4. & $\begin{array}{l}\text { S - use of } \\
\text { synergy }\end{array}$ & $\begin{array}{l}\text { Different forces are combined to achieve an effective goal through a } \\
\text { cluster, and all of them are set to perform their function } \\
\text { systematically in the same system. It is constantly improving to } \\
\text { ensure that it is competitive in the future. As a result, a synergistic } \\
\text { effect is achieved. }\end{array}$ \\
\hline 5. & $\begin{array}{c}E \text { is to achieve } \\
\text { efficiency }\end{array}$ & $\begin{array}{l}\text { All efforts in this system are aimed at achieving high efficiency. } \\
\text { Because all the participants are interested in the result, they unite all } \\
\text { their efforts and strive for economy and efficiency. As a result, as } \\
\text { the efficiency of the entity increases, so does its competitiveness. }\end{array}$ \\
\hline 6. & $\begin{array}{l}\mathrm{R} \text { is the high } \\
\text { result }\end{array}$ & $\begin{array}{l}\text { All of the above processes and factors make it possible to ensure the } \\
\text { effectiveness of the activity. This, in turn, not only increases the } \\
\text { competitiveness of the subjects, but also ensures the interest of all } \\
\text { participants. }\end{array}$ \\
\hline
\end{tabular}

Today, the country is working hard to form a "New Uzbekistan". At the same time, not only the state is emerging as a reformer, but also society as an initiator of reforms. In this regard, in the Address of the President of the Republic of Uzbekistan Shavkat Mirziyoyev to the Oliy Majlis on January 28, 2020, "We have set ourselves the glorious goal of building a new Uzbekistan together with our people. In this regard, the new idea of "Society - the initiator of reforms" is becoming more and more deeply ingrained in our daily activities. In order to increase the practical effectiveness of reforms, we must make our people more active and proactive in promoting new initiatives on the ground. Most importantly, as a result of these reforms, we must create a prosperous and decent living environment for our people. We need to create more favorable business and investment environment and increase the number of new enterprises and jobs so that our people can earn enough income. If we don't do 
this very important thing ourselves, no one will be able to do it for us from abroad, "he said. ${ }^{2}$

The main initiator of this work is, in fact, the society itself. Because almost all clusters are organized and operate on the basis of private property. If necessary, they are provided with loans from commercial banks.

Today, everyone should know that the construction of "New Uzbekistan" will not happen by itself. For this, human thinking and worldview must also change. Because if we import and launch advanced technologies, robots, we will be able to develop the economy very quickly. But it cannot be changed quickly by importing the human mind, thinking, and worldview. We have a long and difficult way to go in this regard. We have not been able to completely get rid of the thinking, worldview and ideology of the old totalitarian era. Today, if we all unite, study continuously, adhere to our values, acquire modern knowledge while restoring faith, do our job perfectly and efficiently, form a society without corruption and strive to advance ourselves, our lives and society will change. But it will not be easy.

As noted by the President, "Digital technologies not only improve the quality of products and services, reduce unnecessary costs. At the same time, they are also an effective tool in overcoming the scourge of corruption - the most serious flaw that bothers and annoys me so much. We all need to understand that. "Because even today, there are various illegal actions with elements of corruption. It was revealed in the control measures carried out by the Department of State Financial Control and its territorial departments on compliance with budget discipline and targeted use of budget funds for

2 Address of the President of the Republic of Uzbekistan Shavkat Mirziyoyev to the Oliy Majlis of January 28, 2020.// “Xalq so'zi” newspaper January 30, 2020.- Pages 1-3.
9 months of 2021. According to the information service of the Ministry of Finance, the deficits and misappropriations amounted to 83.7 billion soums, unjustified and overpayments from the budget amounted to 457.7 billion soums and unintended expenditures -187.3 billion soums. During the reporting period, 365 billion soums of illegal budget expenditures were prevented. ${ }^{3}$

Apparently, we still have a lot of work to do in this regard.

The sad fact is that the number of cases of misappropriation, despite the application of so many measures, is increasing sharply instead of decreasing. In this regard, it was reported that "the identified shortages of funds and material assets, as well as cases of misappropriation (83.7 billion soums) increased by 3 times compared to 9 months of 2020 (28 billion soums)."4

These figures are also given by the relevant ministries. From the general analysis, it can be seen that the ministries that are supplied by almost all budget countries are included in this list. This situation has not diminished in the landscaping departments of khokimiyats. A total of 2.5 billion soums was disbursed in these departments. This was 1 billion soums in 9 months of 2020. So, here, too, the increase is 2.5 times.

In addition, the inspections revealed financial errors and deficiencies of 457.7 billion soums, such as unjustified overpayment of wages and equivalent payments, overstatement of prices for construction and repair work and overstatement of work performed, purchase of goods at a high price. This is 4.5 times more

\footnotetext{
3 https://kun.uz/53617426. 08:14 / 30.10.2021.40597

${ }^{4}$ In that resource.
} 
than in the first 9 months of 2020 (101.4 billion soums). ${ }^{5}$

The legitimate question arises as to whether these can be prevented and eliminated.

It is superfluous to talk about competition where there is corruption. Because an entrepreneur who wants to win in real competition does not deceive the customer, does not betray him, does not reduce the quality of goods (works, services). All of this constitutes honesty. This means that honesty should be a priority for a good competitive environment. This is described in detail in our monograph "Theoretical and methodological problems of the analysis of the activities of private enterprises."6

Where there is corruption, there is no honesty. Therefore, it is necessary to take measures to eradicate this disease. As the President said, we will not be able to achieve our goals without the involvement of all segments of the population, the best specialists in the fight against corruption, all members of our society, if not vaccinated with the "honesty vaccine". We must move from combating the effects of corruption to preventing it at an early stage." 7 . Sufficient information in this regard is given in the scientific recommendation on "Honesty vaccine-means to cleanse the human body and body. ${ }^{18}$

Apparently, an honest profession is said to be "the next duty." Our scholars have also stated that "Honest profession is an obligation that is always valid, that is obligatory, and that it is

\footnotetext{
5 In that resource.

6 Pardaev Mamayunus. Vaccination with the "Honesty Vaccine" means the cleansing of the human body and body. Scientific and educational advice. - Samarkand, SIES, 2021

${ }^{7}$ Address of the President of the Republic of Uzbekistan Shavkat Mirziyoyev to the Oliy Majlis of
}

obligatory even after all the obligations have been fulfilled." This means that honesty is obligatory in Shari'ah sources. Today, in the new Uzbekistan, where our original values are being restored, the "Honesty Vaccine" is one of the most important actions that must be recognized for everyone, for our society. Everyone must be spiritually healthy to practice honesty. That is why he should be vaccinated with the "Honesty Vaccine". The above-mentioned illegal actions in the financial sphere were also committed by people. They do not even recognize honesty as an obligation. In order to understand honesty, one must also have whole faith.

In our opinion, in the cluster method, a chain of work processes is formed and a team consisting of different professions is gathered. This will put an end to deception and illegal actions. Not everyone is prone to breaking the law in a crowded place. Among them are those who know that honesty is obligatory. This manifests itself as a manifestation of collective control. This means that the cluster method can also serve to some extent in preventing irregularities. A synergistic effect is achieved through the cluster method. Because the fact that people, or rather employees, come together also serves as a factor in preventing corruption.

\section{CONCLUSION}

Our conclusions and recommendations developed as a result of the study are as follows:

January 28, 2020.// “Xalq so'zi” newspaper January 30, 2020.- Pages 1-3..

8 Pardaev M.Q., Isroilov J.I. Theoretical and methodological problems of the analysis of the activities of private enterprises. Monograph. - T .: "Science and Technology" Publishing House, 2007. -

Pages 44 
1. The subject of "Education", introduced at all stages of educational institutions, should include a section on "Honesty Vaccine" and a comprehensive study of the need for vaccination.

2. It is necessary to conduct regular vaccinations of employees, especially executives, with the "Honesty Vaccine". It is necessary to absorb from the wealth found in haram that a person will not be greedy in both worlds and will suffer great harm in the Hereafter.

3. It is advisable to vaccinate employees of all links in the currently established cluster entities with the "Honesty Vaccine".

In summary, the UACSER model has great potential in increasing the efficiency of cluster and synergetic utilization. In this way, it serves not only to increase the efficiency of production (work, services), but also to strengthen the competitiveness of entities operating in this area, to eliminate various illegal activities in exchange for the prevention of corruption.

\section{REFERENCES}

1. Address of the President of the Republic of Uzbekistan Shavkat Mirziyoyev to the Oliy Majlis of January 28, 2020.// "Xalq so'zi" newspaper January 30, 2020.- Pages 1-3.

2. Pardaev Mamayunus. Vaccination with the "Honesty Vaccine" means the cleansing of the human body and body. Scientific and educational advice. Samarkand, SIES, 2021. - 44 pages.

3. Pardaev M.Q., Isroilov J.I. Theoretical and methodological problems of the analysis of the activities of private enterprises. Monograph. - $\mathrm{T} \quad$. "Science and Technology" Publishing House, 2007. Pages 97-122.
4. https://kun.uz/53617426.

08:14 / 30.10.2021.40597. 